\title{
Transnational Environments and 'Mixed Signals' in Radio Propaganda: The Voice of America, the BBC, and the People's Republic of China, 1949-1976
}

\begin{abstract}
This paper explores Mandarin-language radio operations broadcast by the British Broadcasting Corporation (BBC)'s External Service Programming and the United States Information Agency (USIA)'s 'Voice of America' (VOA) programming from 1949-1976, particularly the concerns over language among employees as they attempted to shape public opinion across a variety of Chinese-speaking audiences in the 'Far East' region. Using archival, memoir, and oral history sources, I argue that the broadcasting policy concerns of the BBC and the VOA were shaped by an entanglement between national and transnational pressures, particularly over the use of accent, dialect, and terminology which could evoke real or imagined feelings of national identity among transnational listening audiences. As the BBC and VOA staff prioritised certain language, from 'pure' accents to 'acceptable' phraseology for their diverse and disparate listening audiences across mainland China, Hong Kong, Taiwan, Malaysia, 'Burma' and other Chinese-speaking overseas communities, they produced 'mixed signals' which upheld ideas of a unified and homogeneous Chinese nation-state while attracting few to their informational programmes, especially in mainland China. One result of these 'mixed signals' was that many listeners on the mainland and elsewhere valued foreign broadcasts with language-free musical entertainment over informational news. By reconsidering the transnational dimensions of British and American broadcasting in the region, which have long been considered only on national terms, this paper emphasises the role of transnational listening networks in shaping the development of news systems across this diverse linguistic region.
\end{abstract}

\section{Keywords}

radio, $\mathrm{BBC}$, Voice of America, China, transnational, accent

\section{Introduction}

Michelle Hilmes and other scholars of radio and nationalism have noted that radio technology, first glorified in the early twentieth century for its 'invisible, ephemeral, and border-defying 
capacities,' was soon 'harnessed to the will of the nation state' by British and American state-sponsored radio organisations during the World War II period to further define borders, re-assert national identities, and bolster wartime patriotism. ${ }^{1}$ Yet as the informational missions of these organisations expanded and evolved during the Cold War period, transnational environments and imaginations soon became entangled with the nationalist tendencies of radio technology born amidst wartime struggle. The 'inherent transnationalism of broadcasting's cultural economy,' rooted in a technology that provided a site for informational exchange across national borders, often met with language policies defined on national terms, especially in regards to linguistically grey areas where accent, dialect, and localised vocabulary were not easily transcribed onto radio broadcasts designed to speak to (real or imagined) national populations. ${ }^{2}$

This paper explores Chinese language programming broadcast towards the People's Republic of China (PRC) and other Chinese-speaking audiences in the region from 1949-1976, investigating how radio agencies of the era dealt with such entanglements between national imaginations and transnational linguistic realities. I focus on the British Broadcasting Corporation (BBC)'s External Service programming and the United States Information Agency’s (USIA) 'Voice of America' (VOA) Mandarin language programming from 1949-1976, especially how vocabulary and accents were considered by foreign programme directors of Chinese-language radio programmes to appeal to certain domestic and overseas audiences across Mainland China, Hong Kong, Taiwan, and Southeast Asia. ${ }^{3}$

By invoking the term 'transnational,' this paper intends to first emphasise the ways in which real people involved in BBC and VOA radio programme production, primarily Mandarin and Cantonese translators and editors of $\mathrm{BBC}$ and VOA news content, were often defined on national terms despite the complexity of identities and space which such individuals occupied, between the diverse listening populations they were meant to speak to and the British and American Cold War empires they worked for. Second, the term 'transnational' is meant to evoke the technological ability of radio broadcasts to provide access to information to a variety of audiences across and between national borders in the East Asia and Southeast Asia region discussed herein. Despite BBC and VOA programme producers' desire to broadcast informational and cultural propaganda to an imagined Chinese national audience, this paper demonstrates how the geographic accessibility of radio broadcasts beyond national borders and across a diversity of linguistic landscapes often puzzled producers' attempts to consolidate a unified language policy among broadcasts towards such imagined audiences. 
In particular, I explore the peculiarities of this 'national media with a transnational mission'4 by asking whether British and American radio organisations' fixation on 'national language' in their broadcasts towards Chinese-speaking audiences tended to conceal and silence the reality of local language diversity, interpretations, and experiences. ${ }^{5}$ I assess whether such a fixation on language standardisation and dialectical purity offered yet another avenue of media through which nation-states, in this case the People's Republic of China, have consolidated a narrative around language as fixed on the standards of a national centre. ${ }^{6}$ In addition, producers' concentration on language standardisation also offers a lens through which to understand the voices of those who did not fit within such parameters. Speakers of dialectical variants and subscribers of a wide range of political and linguistic ideologies beyond the imperatives of these national propaganda missions and across national borders in the region largely used British and American programming as a medium to listen to language-free musical programming despite linguistic differences of the region. Other research has productively discussed this 'dilemma of language use' and 'differences in political cultures' between national broadcasters and target audiences in regions such as India and Pakistan, yet analyses of these uniquely transnational radio environments have been slow to explore the incredibly diverse range of language and politics exercised by Chinese-speaking audiences across mainland China, Hong Kong, Taiwan, and Southeast Asia during the second half of the twentieth century, a period marked by rapid change in politics and language among Chinese-speakers in the region. ${ }^{7}$

My research on this subject finds first that British and American radio programme organisers were very concerned with the concept of a 'national language' in China during the period of study from 1949-1976. Yet as the political vocabulary within the 'national language' of the People's Republic of China shifted rapidly under the newly established Communist government, British and American programme producers' attention tended to focus on the dialectical 'purity' of their Chinese language programming while ignoring an increasing diversification of everyday Chinese-socialist vocabulary. I also find that the directors of BBC and VOA programming were confronted with the challenges of a transnational linguistic and political reality. Informational missions of the BBC and VOA programming emphasised the need to convince Chinese speaking listeners of the legitimacy of their broadcast information and accompanying ideological stances across the PRC, Hong Kong, Taiwan, 'Burma,' Thailand, Vietnam, Malaysia, and everywhere else their short- and medium-wave transmitters in the region broadcast Chinese language programming with clarity. Yet their fixation on 
standardised 'Peking 'kuoyu' accents' and disengagement with everyday Chinese-socialist vocabulary often left them speaking only with an imagined Chinese nation. Instead of engaging with the diversity of political views and perspectives among Chinese speaking audiences, United States Information Agency officials found only a mediocre resonance of their Chinese-language broadcasts in what they described as 'the uncommitted nations' of the region. ${ }^{8}$

Chinese-speaking listeners across this transnational listening space instead overwhelmingly tuned in to the musical programming provided by the BBC and the VOA, as shown by statistics gathered by both organisations and post-1976 testimony collected from PRC citizens. By choosing to circumvent the more overt propaganda objectives of each agency in favour of language-free musical entertainment, listeners' choices reflected the unique power of transnational cultural economies which expressed musical appreciation beyond the confines of national language, boundaries, and borders. ${ }^{9} \mathrm{~A}$ renewed focus on this particular listening choice offers a new angle through which researchers can 'spatialize power' beyond the propaganda missions of nation-states, focusing on these listeners' shadows in archival material rather than BBC and VOA producer's nation-centric propaganda imperatives. ${ }^{10}$ These networks appear to have leveraged the technology of radio to craft identities through music rather than politics, listening and existing beyond the immediate propaganda agendas of nation-states' programming.

I intentionally label the informational content of the British (BBC) and American (VOA) radio agencies Chinese-language programming as 'propaganda,' which in this region took the form of news, cultural features, interviews, and political commentary. By 'propaganda' I refer not to purposefully misleading information - what the British and American radio operators discussed herein referred to as 'black' propaganda - which was certainly present across the Chinese-speaking radio waves in this region. ${ }^{11}$ I instead focus on what American and British broadcasting policy throughout the Cold War period increasingly referred to as 'public diplomacy,' or the 'cultivation by governments of public opinion in other countries. ${ }^{12}$

More specifically, British and American programme directors exercised a version of public diplomacy in the region by insisting on the consolidation of language through accent, vocabulary, and dialect based off of a 'Peking 'Kuoyu' accent,' while rejecting the use of Chinese-socialist vocabulary in their daily broadcasts. As Philip Deery has noted in his study of British radio and print propaganda in Malaya, this strategy of deploying homogenised language within propaganda broadcasts was 
intentional. In anti-Communist propaganda material directed towards Malaya during the late 1940s, British Information Research Department (IRD) officials recommended 'the persistent use of particular words or phrases to convey a meaning (...).' For example, IRD officials doggedly used the word 'Kremlin' in broadcasts, which was designed to characterise Russian communism as originating from a central body which could then be coloured as sinister, graphic, and manipulative. ${ }^{13}$ British and American officials were known to exercise similar linguistic methods of 'public diplomacy' in Chinese-language broadcasts; all mention of American actions in Vietnam after 1965 were referred to by the BBC and VOA as 'operations,' ${ }^{14}$ whereas domestic Chinese media was more likely to label the American actions in Vietnam as 'imperialism' or 'aggression'. ${ }^{15}$ As the incredibly powerful idea of a 'national language' emerged throughout the twentieth century, nation-states in a variety of settings used similar strategies to fix language, set an agenda for standard communication, and mobilise language to unify populations in support of political projects both at home and abroad.

\section{Notes on sources and scope}

The period chosen for study (1949-1976) is not necessarily interesting because of its concurrence with the ongoing socialist revolution in mainland China, but because it reflects a moment in global history during which language across this region became acutely politicised, not only by the 'modernising' state-sponsored projects of domestic actors, but as we have seen, also by the British and American radio state-sponsored organisations operating in this region. Rich discussions of language, dialect, and deployment of nationalist-communist terminology by the BBC and VOA from 1949-1976 are stored in the National Archives and Record Administration, Maryland, US (NARA), The National Archives of the United Kingdom, Kew, UK (TNA), and the British Broadcasting Corporation's Written Archive Centre, Caversham, UK (BBC WAC). Months of research in these spaces unearthed a wide variety of documents, photographs, and correspondence between British editing sections of Chinese language programming in London, Hong Kong government officials, Information Services Department (IRD) staff in charge of British propaganda policy, British diplomats stationed in Beijing, research staff within the US Army (Rear) Office of the Psychological Warfare Officer, American officials of the International Broadcasting Division of the State Department, and American operatives of the United States Information Agency, among other materials. These archives reflect a strong degree of cooperation and information exchange between the BBC External Service Programming and 
the United States Information Agency, and their paired archives house an ongoing historical conversation over language policy and the dilemmas of transnational broadcasting in the Chinesespeaking region. Archival material is supplemented by recorded oral histories of American individuals who worked within the USIA's Hong Kong offices and others who were in contact with British and American intelligence and broadcasting work in the region. ${ }^{16}$

Chinese-speaking listeners' reactions to such programming is more difficult to locate, but exists in informal spaces of online social exchange and more formal memoirs and personal essays which reflect listeners' engagement with BBC and VOA Chinese-language content. These spaces are filled with nostalgic reminiscence, as many listeners recall listening to foreign radio fondly, mostly for musical content as curious teenagers. This paper builds on excellent research of the Chinese-socialist past which has leveraged such online materials to analyse the dimensions of post-reform nostalgia among 'sent-down youth' (zhiqing) who travelled to the countryside in the late 1960s and early 1970s, and later reflected on their experiences in online spaces in the 1990s. This paper also utilises evidence of domestic Chinese listening habits from the archival spaces mentioned above (NARA, TNA, BBC WAC), which contain the results of British and American intelligence agencies' missions to collect interviews on radio listening habits from Chinese refugees who left the mainland for Hong Kong.

\section{A fixation on dialectical 'purity'}

The deployment of ideas surrounding 'pure' language and dialect/accent/vocabulary has played out across a variety of historical landscapes, and is by no means limited to China, or the American and British officials who prepared programmes to broadcast to the Far East. ${ }^{18}$ The Chinese Communist Party after 1949 in some cases mirrored the multiple language standardisation projects of the twentieth century by continuing the modernisation efforts of previous Chinese state authorities. Dynastic officials of Imperial China in the $19^{\text {th }}$ century, Chinese intellectuals at the turn of the century, and Republican-era governments of the early twentieth century all made some attempt to standardise mandarin Chinese as a form of vernacular 'common speech' (putonghua) across the Chinese mainland, whether through ideological arguments, consolidated state policy, or a combination of both. ${ }^{19}$ What all these social groups across space and time typically agreed upon is that language could be infused with power and authority, along political, racial, or class lines, often to the benefit of one speaking group over another. 
Employees of the BBC operating in Chinese-language service operations were well aware of the use of accent as a powerful tool of standardised English, as the 'Received Pronunciation' (R.P.) accent of many BBC announcers at home came to be identified with 'proper' English and tended to reflect a certain social and class status among speakers. ${ }^{20}$ American radio directors were also acutely aware of the value of language and radio as a political tool, in part due to the precedent in language standardisation set by their peers at the BBC. ${ }^{21}$ American networks, such as CBS and NBC, trained their announcers in 'correct and standard pronunciation' throughout the 1930s, relying in some cases on the works of linguistic purists such as the English Frank Viztelly who wrote language advice books that sought to 'maintain the purity of our language' and to 'iron out certain jarring irregularities' from radio broadcasts. Radio historian David Goodman suggests Viztelly’s motivations for language 'purity' were raised along racial and class lines, as Viztelly saw the English language as under threat from the intrusion of immigrants and their accompanying foreign accents. ${ }^{22}$

In the Chinese case, 'Putonghua,' sometimes referred to as 'standard' Mandarin or 'modern' Chinese, was developed based on the Beijing and/or Northern dialect, and should be recognised as a constantly evolving ideological project that never truly reflected social realities which embraced a diversity of local dialects (fangyan). Chinese-language speakers at home and abroad largely grew up speaking regionally specific versions of Chinese in their homes and only heard a version of Beijing-style Putonghua through modern media such as radio or television broadcasts during the Republican and high-socialist (1949-1976) periods. ${ }^{23}$ Overseas Chinese communities in the first half of the twentieth century likewise held a vast linguistic diversity in Mandarin, Cantonese, Amoy, and other dialects that adopted new terminology, sometimes Chinese-socialist vocabulary, which could be associated with national and political implications throughout the second half of the twentieth century. But as scholar of South East Asian diaspora Siew Min-Sai has pointed out, even as these groups adopted Chinesesocialist terminology they were not necessarily responding to any cultural authority emanating from a Chinese language centre on the mainland, and were instead participating in a more global moment of Chinese nationalism which evolved alongside politics of decolonisation in the region. ${ }^{24}$

\section{How did listening occur?}

Chinese mainland radio audiences under high socialism had access to an ever-increasing amount of domestic radio programmes, from educational content with a clearly pro-Communist Party message 
to more apolitical reports of weather forecasts and folk music. ${ }^{25}$ But a turn of the dial away from such domestic radio were a wide variety of global actors seeking the ears and attention of Chinese citizens, including the United States' 'Voice of America' (Meiguo zhiyin) or VOA for short, the United Kingdom's 'British Broadcasting Corporation' (Yingguo guangbo gongsi) or BBC, the Soviet Union's 'Radio Moscow' (Mosike diantai) and the Taiwanese-Guomindang 'Voice of Free China' (Ziyou zhongguo zhisheng), all of which poured countless resources into developing Mandarin and Cantonese language radio broadcasts designed to influence public opinion in Mainland China. Domestic Chinese propaganda campaigns and national laws vilified foreign stations as 'enemy radio' (ditai), put into place strict measures for registering private radios by 1955, and punished those who listened to foreign radio as potential enemy spies or secret agents $(t e w u)$, but it is clear that when the conditions aligned, many mainland Chinese citizens tuned into foreign radio despite the risk. ${ }^{26}$

The BBC's Chinese language programmes operated in this region from 1949-1976 under the name of the 'BBC External Service’ with the aid of local BBC affiliate 'Radio Hong Kong,' which relayed signals from London through Tebrau (Malaysia) and Cyprus on shortwave and medium wave channels. ${ }^{27}$ By 1951, the BBC broadcast live programming from London for 45 minutes a day (30 minutes in Mandarin, 15 minutes in Cantonese) at 11:00 Greenwich Mean Time (19:00 China Standard Time), and in 1964 the BBC would increase their broadcasting to mainland China from 45 minutes to a full two hours a day (90 minutes of Mandarin and 30 minutes of Cantonese), divided into a morning, early evening, and 'peak-listening' late evening block. ${ }^{28}$ The BBC and its Chinese language services were not a direct arm of the British government and were officially considered an 'independent organisation,' unlike their counterparts at the VOA in the USA. While the BBC technically maintained independence from the British government, the Foreign Office administered parliamentary funding for programming which dictated 'where, when, and in which languages the BBC broadcasts,' and the $\mathrm{BBC}$ was technically chartered to 'plan its programmes in the national interest' by keeping the Foreign Office 'closely informed of the contents of its programme to foreign countries. ${ }^{29}$ According to historian Michael Nelson, the BBC was closely advised on the tone and content of news programming by the Information Research Department of the British Foreign Office, an anti-Communist department funded by secret vote and designed to oversee British anti-Communist propaganda. ${ }^{30}$ The parliamentary funding stream of the BBC ended with local affiliates such as Radio Hong Kong, which were established by the British Government of Hong Kong and received some public subsidies from the local government alongside licensing fees rendered to Radio Hong Kong subscribers. ${ }^{31}$ 
Meanwhile, American broadcasting efforts in the China region were organised by the USIA, a branch of the US State Department which developed and broadcast VOA programming from Washington D.C. after 1953. Radio broadcast towards mainland China played first in San Francisco, where a primary shortwave signal was boosted by two 100 kilowatt shortwave transmitters in Honolulu, and then boosted again by three more transmitters in Manila, Philippines. ${ }^{32}$ Some VOA programmes in Mandarin and Cantonese were broadcast directly from San Francisco, while others were developed, produced, and taped in Washington, D.C., New York, or Hong Kong then sent to outlets in San Francisco and throughout the world, (this practice was deemed 'package programming'). ${ }^{33}$ Anti-Communist propaganda angles of the VOA were more overt than the BBC, as the Smith-Mundt Act of 1948 empowered the VOA to initiate 'the government's intensified psychological offensive' characterised as a 'Campaign of Truth' which was designed 'to weaken the forces of Communism, to diminish its power (...) among people who are now beguiled by false propaganda and threat of arms (....). ${ }^{34}$ As of 1952, three hours of Mandarin and one hour fifteen minutes of Cantonese daily radio broadcasting reached almost all of Chinese landmass, and could be heard as far North as Harbin and as far West as Ningxia, although listening conditions depended heavily on local circumstances (i.e. elevation, clear skies without weather or tree coverage, etc.). ${ }^{35}$ By 1958, original programming had been increased to four hours of Mandarin and two and a half hours of Cantonese.

The two broadcasting entities (the VOA and the $\mathrm{BBC}$ ) were highly integrated via a pooling of intelligence resources. They shared intelligence reports on 'Communist China' and held the technological and institutional means to exchange monitored and transcribed radio materials broadcast from China between their monitoring headquarters in Caversham, UK and Washington, D.C. via 'high speed radio telegraphy circuits. ${ }^{36}$ The 'harmonious interests' of British and American intelligence pooling resulted in the establishment of consistent communication between the Foreign Broadcast Information Services (FBIS) in Washington D.C. and British Monitoring services in Caversham, UK, which circulated informational materials to appropriate Chinese-language broadcasting functionaries in London, San Francisco, and overseas. Intelligence resources from the FBIS and British monitoring services then shaped the following Chinese-language news programming developed and broadcast by the BBC and VOA. While a sharing of intelligence resources may have led to an integration of understanding over Chinese political aims, the two organisations' outward broadcasting policy towards Chinese-language listeners in the 'Far East' was certainly distinct in tone 
and content. Evidence suggests that the $\mathrm{BBC}$ chose to 'emphasize the weakness of Communism rather than its strength' while 'American propaganda (...) stress[ed] the strength and aggressiveness of Communism. ${ }^{37}$ A later summary of a public opinion poll among Chinese-speaking listeners in the region summarised the disparity between the BBC and the VOA by comparing them to 'an oldfashioned British gentleman' and an 'arrogant Yankee,' respectively. ${ }^{38}$

\section{The transnational dilemma of radio waves}

Overseas Chinese ('huaqiao' emigrant Chinese or 'huayi' those of Chinese descent living abroad) subscribed to an incredibly diverse range of politics and varying degrees political ties with the mainland while sharing only language and highly varied feelings of nationality or 'homeland' sentiments with their mainland counterparts. But radio waves broadcast throughout this region could not be narrowcast to specific listening audiences, and while the BBC and VOA could direct their programming towards certain geographies, there was no way to limit their programme audiences to certain nationalities or political affiliations. As a result, the question arose of how 'news' directed at mainland China, the BBC and VOA's largest and most important audience due to size and the Cold War political climate, would be received by the multiple and diverse range of Chinese speaking audiences outside of the PRC's national borders. An information officer of the South East Asian Department Services of the BBC summed up his position on the matter tersely: 'Overseas Chinese constituted a different type of audience from Chinese in China and it was anomalous to give both the same programme. 39 'Overseas' audiences generally concurred with this line of thought; research shows that there was often a recognisable divide between content directed towards mainland Chinese and content directed towards overseas communities, which could be viewed as undesirable or irrelevant by both listeners. ${ }^{40}$ But neither the BBC nor VOA was able to overcome this particular difficulty, partially because further diversification of Chinese language programme material was an expensive endeavour, but also because radio content was extremely difficult to direct towards one specific community without confusing multiple audiences. ${ }^{41}$ And while Wanning Sun, John Sinclair, and others have conducted research on the contemporary contexts of Chinese-language media among ethnic Chinese in Southeast Asia, few studies have yet to focus on how the historical Chinesespeaking diaspora in this region may have engaged with radio broadcast media during a time of intense political battle over the Cold War airwaves. ${ }^{42}$ 
At the $\mathrm{BBC}$ and the USIA, the issue of radio broadcasting to diverse listening audiences across national borders often returned to the question of language, particularly how best to deploy accents and phraseology with the political, ideological, and national diversity of listeners in mind. In a discussion of whether or not their broadcasts sounded like mainland Chinese speech or like foreign 'overseas' language, a Chinese-speaking counsellor wrote in a letter to the BBC on February 28, 1951 that 'the vocabulary, and particularly the political vocabulary, that is in use in China today is entirely different from what was in use only a few years ago, and anyone who has been out of touch will at once show it. ${ }^{43}$ An Information Research Department officer in London echoed issue of access to up to date vocabulary in 1955: 'One other thing is the question of language and standard. We badly need newspapers from the mainland as a source of up to date phraseology, technical terms, language usage, and so on,' and asked for more newspapers from Humphrey Trevelyan, the British Charge D'Affaires stationed in Beijing. ${ }^{44}$ Donald MacFarlane, member of the IRD, ${ }^{45}$ wrote to Eric Robertson, head of the 'Far Eastern' Services department of the BBC which oversaw Chinese language programming, noting that 'it is no doubt that the new Chinese government has made many alterations in the language and must have introduced Communist terms into the political vocabulary which have now become current and accepted in daily use. The BBC would probably not want to adopt this ideological vocabulary. ${ }^{36}$ By 'ideological vocabulary,' the Information Policy Department referred to terms such as 'proletariat' (wuchanjieji), 'political consciousness' (zhengzhi jiewu) or referring to present times as 'after liberation' (jiefang yihou) as Chinese speaking individuals and official state-sponsored radio and print media often did on the mainland.

The employees of the BBC Chinese language services were more apt to weigh the pros and cons of such 'ideological vocabulary' and its impact across transnational audiences carefully as they edited broadcast content. But their counterparts at the British Foreign Office appeared more likely to weigh the political impact of $\mathrm{BBC}$ broadcasts in the 'Far East' region over any transnational linguistic nuance. A British Foreign Office Committee convened in 1952 to 'examine overseas information in terms of function, organization, and political aims,' summarised their information goals in the 'Far East' with a national and political edge: 'To maintain and develop each country’s independence (...) with a view to increasing the desire and ability of the whole area to resist communism from within and without. ${ }^{47}$ According to the same report from the Foreign Office, overseas information services in Southeast Asia and China, including English lessons broadcast via the radio, informational news, and cultural features, 
formed part of a single process, designed to condition the thinking of a selected number of educated Asians in such a way that a great deal of goodwill towards the United Kingdom will be created among (...) politicians or industrialists in the New Asia. ${ }^{48}$

Whether due to pressure from the Foreign Office, other political reasons, and/or the difficulty of staying 'up-to-date' with appropriate Chinese-socialist terminology, the BBC's Chinese language programming chose not to adopt such socialist and 'ideological' vocabulary in broadcasts. However, the $\mathrm{BBC}$ did manage to inject some language into broadcasts that would have been more politically digestible for listeners who found themselves in alignment with the Communist politics of mainland China. A 1965 USIA survey at the American Consulate in Hong Kong found that the BBC was more generally trusted on the mainland because BBC producers recognised official titles of the PRC government, deploying terms such as 'People’s Republic of China' and 'Prime Minister Zhou En-Lai,' which the Americans did not. ${ }^{49}$ Careful editing also points towards political tiptoeing in regards to language on the part of BBC Mandarin language programme editors. In a statement that read 'the bureaucracy is the class that Marx forgot, the class that may own nothing and enjoy everything,' the editor was careful to add 'the bureaucracy is the class Marx forgot and Chairman Mao remembered [bold original]. ${ }^{50}$ Such editing runs throughout the BBC programme's Chinese translations, and suggests a politically sensitive attitude on the part of unnamed BBC Chinese programming staff at the script editing level.

American producers, on the other hand, did not recognise the legitimacy of the People's Republic of China or its government by using proper names and titles in their programming. ${ }^{51}$ The Voice of America referred to the mainland as 'Zhonggong' meaning 'Communist China,' referred to Beijing as 'Beiping,' the Guomindang term for the capital which did not acknowledge the Chinese Communist Party's establishment of a capital in Beijing, and occasionally cited Chiang-Kai Shek and other Republic of China (ROC) Nationalists in broadcasts who used the term 'gongfei,' meaning 'Communist bandit'. ${ }^{2}$ This vocabulary had clear political intentions, especially when counterposed against the terms they used to describe the Nationalist Guomindang government in Taiwan, which included Ziyou Zhongguo (Free China). From 1949 until at least 1968, domestic politics and general anti-Communist fervour in the United States encouraged such harsh rhetoric, and the VOA occasionally came under Congressional scrutiny for their inability or refusal to deploy even more anti-communist wording and material in broadcasts. ${ }^{53}$ As head of the Voice of America Chinese 
Branch brought up in a memo to the State Department in 1968, these terms were not the best way to establish a meaningful connection with listeners on the mainland, noting that mainland Chinese audiences would probably 'turn off right at the beginning of our broadcast' when they heard offensive vocabulary like 'Beiping,' or 'Zhonggong'. His suggestion was 'we better start using language that they accept,' which was acknowledged by State Department staff and became one aspect of a thaw of relations that resulted in President Richard Nixon's visit to China four years later. ${ }^{54}$

\section{'Purity' of accents}

Perhaps even more important to Chinese programme organisers in the BBC and VOA than terminology and vocabulary was the question of dialectical 'purity.' Historical evidence suggests that it was important for programme directors to determine whether their announcers sounded like they were not only from the mainland, but also speaking the official political dialect of the PRC and the Chinese Communist Party, referred to as 'Putonghua,' 'Guoyu' (or 'Kuoyu'), 'Huayu,' 'Mandarin,' or 'standard Chinese'. This issue of language 'purity' among Chinese programme announcers in the BBC and VOA often reflected a genuine desire to engage with Chinese mainland listeners, but actually appears to have turned into a hyper-focused search for 'pure' Chinese speakers that ignored more serious barriers to engaging with listeners on the Chinese mainland. A 1951 report to the BBC 'Far East' director Donald MacFarlane noted 'The Chinese Service suffers from the fact that it uses oldfashioned 'Kuo-Yu' with an accent that is sometimes heterodox, which at once makes it slightly ridiculous to present day Chinese listeners. ${ }^{55}$ But heterodox (divergent or irregular) accents weren't the only criticism fielded by the BBC, as one British listener in Shanghai complained that 'the broadcast appears to be given by a foreigner with a Szechuanese accent. ${ }^{56}$ Another British listener confirmed this observation, saying 'the person who reads the news in Chinese in the BBC's Far Eastern section has a strong Szechuanese accent. ${ }^{57}$ The same observer tied politics to accent by stating, 'such an accent, apart from sounding harsh to the educated ear, is associated in the minds of most Chinese with Chungking, and therefore indirectly with the much hated Chiang Kai-shek, whose seat of government was at Chungking during the war years. ${ }^{58}$ Both British listeners considered the Sichuanese accent of the Chinese-speaking announcer as holding potential political or class meaning, and thus suggested a change in staff at the BBC, while commenting little on programming content or what those listeners currently living in Sichuan or elsewhere may have thought of such broadcasts. 
The concept of 'purity' in accent was also mobilised to raise the issue of a supposed 'Chineseness' among programme organisers. As a result of questions over proper Chinese accents in $\mathrm{BBC}$ broadcasts, a programme director of the $\mathrm{BBC}$ Chinese programme staff defended the use of their Chinese-speaking translators and writers by noting

A great proportion of our Kuoyu (Mandarin) broadcasts are written by Chinese graduates of Chinese universities (...) [and they would not] broadcast that which they did not consider reached at least an average standard of Chineseness. ${ }^{59}$

Donald MacFarlane was forced to defend the qualities of his Chinese programming staff and their accents on similar, national-dialectical terms, noting

Y.K. Lung speaks the purest Northern Kuoyu, while C.J. Chen's departures from it are no greater than those from standard English to be heard from Home Service announcers (...) F.K. Liu's occasional consonantal transpositions are noticeable, and in news reading may dissatisfy the purist, but he is perfectly clear and in no sense 'rustic' (...).

MacFarlane added to the discussion that hiring a broadcaster with a high degree of 'Chineseness,' measured by a 'pure' Peking accent, was complicated by issues of political reliability, because 'it is of course difficult for [the $\mathrm{BBC}$ ] to recruit any staff with recent experience of China who could also be regarded as politically reliable. ${ }^{60}$ In criticising announcers' accents, tying accents to 'Chineseness,' and then tying 'Chineseness' to political reliability, BBC staff appear to have unwittingly upheld the nationalist visions of a Chinese nation-state bounded by a singular, uniform language and a certain degree of Chinese cultural authenticity emanating strictly from the mainland.

The BBC also collected information from Chinese overseas and domestic listeners in the 1950s through letter writing contests, several letters of which came from 'Communist China.' When the topic of accent, pronunciation, and dialect was raised by 55 listeners from all across Southeast Asia, Hong Kong, mainland China, and Taiwan, Chinese-Section Programme Director P.G.E. Nash reported 'pronunciation of Kuoyu is a subject on which the Chinese are remarkably faddy,' meaning having very strong yet divergent preferences on the subject. ${ }^{61}$ During a similar letter-writing contest four years later, he again noted 
It is a fact that the Chinese are quite 'faddy' in the pronunciation of Kuoyu [Mandarin] and the entries to this competition included a good deal of criticism of both general and particular nature. Some announcers came 'under fire' regarding the quality of their broadcasting from certain entrants, while others praised these announcers in general terms. ${ }^{62}$

While the fact that so many listeners were either very happy or very displeased with accent and dialect of Chinese programme announcers at the $\mathrm{BBC}$ could have been taken as reflecting the linguistic diversity of the region, the BBC programme directors and staff came to a different conclusion on subject.

Whether or not any of this feedback on accent and dialect was conclusive, it drew a serious institutional response from the $\mathrm{BBC}$, who organised a pronunciation and accent training protocol on the basis of radio materials broadcast directly from Beijing. As Nash stated in 1955, 'I am having recordings of other broadcasts made in Chinese, included Peking, for the sake of comparison [with BBC broadcasts]. This should help in arriving at some sort of optimum standard. ${ }^{36}$ This protocol remained in effect through 1965, when officials used testimony of Chinese refugees in Hong Kong to reaffirm the policy by noting that the language, pacing, and tone of BBC's announcers 'might strike chords of unfamiliarity in the ear of the listener on the mainland.' They recommended 'listening carefully to tape recordings of Radio Peking's Chinese broadcasts as being the standard and style of language and presentation to be aimed at. ${ }^{64}$ Again, these efforts to align tone and accent among BBC programming with Beijing-style mandarin Chinese upheld and perpetuated the concept of a unified, homogeneous nation and national language of 'China' projected by both British announcers and the PRC state.

\section{Chinese audience reaction to BBC and VOA broadcasts}

While BBC and VOA officials wrung their hands over reaching an appropriate 'standard' in Chineselanguage pronunciation, the question remained, what did mainland audiences think of such programming? Both British and American intelligence agencies were highly concerned with whether or not Chinese citizens on the mainland were listening to their radio programmes and collected as much data as they could on the subject even amidst their limited informational circumstances. Some reports of listening relied on informal rumour, as with a report that merchants from Canton visiting 
Hong Kong for trade in 1950 said that they looked forward to big Communist party demonstrations, since 'only during these hours are people free to talk and listen to the VOA when all Communist agents are occupied with the propaganda campaign. ${ }^{35}$ Other information could be gleaned from interviews with recently escaped refugees to Hong Kong conducted by both British and American officials in the territory. This information formed a very biased sample set made up only of political refugees, but at least proved that some PRC citizens listened to the BBC and VOA Chinese language programmes when they had the opportunity. ${ }^{66}$ For example, in a 1958 sample group of nineteen individuals, six claimed to be daily listeners of VOA broadcasts, mostly tuning into musical broadcasts. ${ }^{67}$

This and other reports from Hong Kong revealed an even greater Chinese predilection on the mainland for music, particularly language-free 'light' music (i.e. orchestral music). In 1955, the USIA in Hong Kong conducted a survey of refugees in this style and shared their results with the BBC. The report clearly highlighted a disposition of Chinese listeners to listen to foreign broadcasting primarily for musical entertainment. For example, $67 \%$ of listeners claimed they tuned in to foreign radio in order to listen to music, with $47 \%$ ranking 'Western popular songs' as the favourite among respondents after classical music. ${ }^{68}$ These same listeners may have ignored informational broadcasts in favour of music; to the question 'has anything you have heard on the BBC or VOA changed your ideas?' the report stated that 'virtually no response [came] from those interviewed. ${ }^{69}$ A later refugee in 1965 firmly claimed he could discuss foreign radio news with one close friend, could listen to light music from foreign stations without fear of persecution, and that quite a few people in Canton tuned in to Radio Hong Kong regularly to listen to such music from the BBC. ${ }^{70}$ Jazz or pop music, meanwhile, would likely arouse suspicion from authorities and the report notes that it was dangerous to listen to jazz, since this obviously came from a foreign station (...) in the case of other light music from a foreign station the excuse could always be made that it was from Shanghai or Peking. 71

Despite the many dangers of listening to foreign stations, post-1980 testimony in the form of online blogs, memoirs, and other recollections also confirm that a considerable number of individuals still listened to foreign radio stations throughout the 1950s, 1960s, and 1970s. ${ }^{72}$ The well-known author and screenwriter Zhong Acheng wrote about listening to broadcasts from Taiwan, Moscow, Australia, and the BBC and VOA during his time spent in Yunnan in the early 1970s. ${ }^{73}$ He particularly liked the $\mathrm{BBC}$ live entertainment programmes, and had a notch marked on his radio broadband that noted the frequency at which the BBC broadcast Mandarin language programming. ${ }^{74}$ Though Zhong 
did not speak English, he tuned in to English language programming to listen to concerts for their entertainment appeal. Even Zhong's village branch secretary supposedly enjoyed listening to 'enemy' radio broadcasts from Hong Kong, which people in the village would tease him about as an open secret. ${ }^{75}$ As Zhong remembers, 'We didn’t just listen to enemy radio for political news, a principal factor was also entertainment. ${ }^{36}$ Other ingenious ways to listen to foreign radio shared by internet bloggers in later recollections of the period included making simple radios out of a soapboxes, a fairly common practice among 'sent down youth' in the countryside in the late 1960s and early 1970s, which was aided by commonly available technical manuals like those pictured below (See Fig. 1$){ }^{77}$

Yet another individual living in Beijing suburbs remembers tuning into Moscow Radio in 1973 with his brother, whose time in the relatively isolated countryside in remote Heilongiiang allowed him to become familiar with Taiwanese, American, British, Hong Kong, and Australian radio broadcasts in that region. ${ }^{78}$ Another recollection from a blog post on listening to foreign radio from the BBC, VOA, and Taiwanese stations in the 1970s recalls that the author's mother once asked him, 'Son, why are you always playing gongs and drums at night?'79 The son was actually listening to foreign radio in secret, likely folk music broadcast from the VOA or Taiwanese radio, or perhaps had stumbled upon the standard PRC jamming technique of playing folk music over foreign radio bandwidths. ${ }^{80}$ After 1972 with the softening of foreign relations in the wake of Nixon's visit to the PRC, listening to the BBC and VOA in mainland China became even more widespread, as reflected by letters written to both offices from the mainland and on-the-ground testimony of British and American visitors to the People's Republic of China. ${ }^{81}$ Clearly, the BBC and VOA had some listeners in China from 1949-1976. As the testimony shows, during some political climates these stations attracted more and at other times fewer listeners, and the opportunity for listening always depended on shifting local and personal conditions.

\section{Conclusion}

Archival evidence suggests that British and American announcers chose to identify with a certain 'pure' Beijing-style Mandarin dialect in tune with trends of language standardisation on the mainland, while at the same time debating the use of up-to-date socialist terminology when addressing their audiences. This process of language 'purification' was flexible, incomplete, and did not play out the same in both examples of radio media (the BBC and VOA) represented herein, yet 


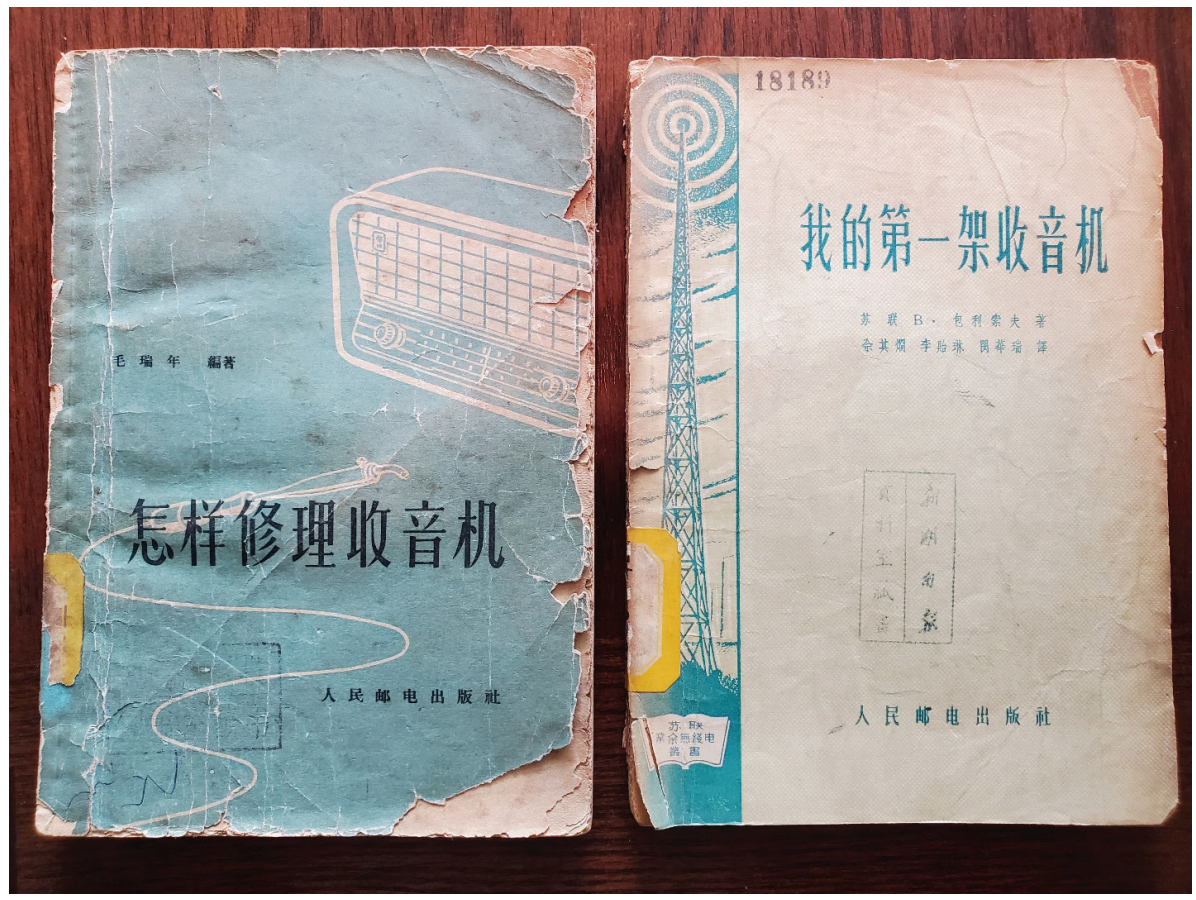

Figure 1. Chinese-language pamphlets with technical instructions on personal radio construction and engineering. Left - Mao Ruinian, ed., Zenyang xiuli shouyinji [How to Repair a Radio Set] (Beijing: Renmin dianyou chubanshe, 1959). Right - Bolisuofu [V. Borisov], Wo de diyi jia shouyinji [My First Radio Set], trans. Yu Qijiong, Li Yilin, and Min Huarui, trans. (Beijing: Renmin Dianyou Chubanshe, 1956). Author's collection.

suggests a clear objective of each institution. The PRC government in the late 1950s likewise saw local dialect as 'problems' (wenti) or 'obstacles' (zhang'ai) in the promulgation of Putonghua (standard speech), a formulation which the BBC and VOA Chinese-language broadcasters seem to have wittingly or unwittingly reinforced through their fixation on 'pure' and 'true' Chinese-language voices modelled off of Beijing style putonghua. ${ }^{82}$ This is not to say that the BBC and VOA were complicit or effective in erasing dialectical variants in China, as it is again important to remember that about $80 \%$ of PRC citizens alive today grew up speaking a dialectical variant (fangyan) in their home. ${ }^{83}$ What the $\mathrm{BBC}$ and VOA did contribute to was a powerful and meaningful amplification of state power through language. This is made especially clear when taking a transnational historical approach and focusing on the shadows that transnational listening audiences left in archival material. Amidst this situation, the BBC and VOA's decisions regarding the sociolinguistic factors of broadcasting policy contributed to a 'state effect' which projected national language as an inevitable and unstoppable aspect of modern progress. ${ }^{84}$ Yet the musical preferences of a transnational listening landscape across 
mainland China, Hong Kong, Taiwan, Southeast Asia, and anywhere in range of BBC and VOA broadcasts reflects how listeners choices often belied such state-sponsored propaganda projects.

Such listeners tended to reap what they could from foreign propaganda broadcasts, navigating between state-sponsored information projects, the possibilities of radio technology, and personal listening choices. The results of this process are represented in part by the transnational radio-scape that developed around BBC and VOA broadcasts, which partially ignored the nationalist imaginings of standardised language in favour of language-free music that accorded with a transnational linguistic reality. As Barbara Mittler has demonstrated in other works on music across this region, a transnational, language-free exchange of music across national boundaries maintained deep roots in the area throughout the high-socialist period, and still remains a powerful cultural force to this day. ${ }^{85}$

The breadth, depth, and impact of this transnational musical network are difficult to trace and mostly reside beyond the scope of this paper. As other studies of BBC World Service music programming suggest, the 'cosmopolitan wrapping' of musical programming broadcasts towards foreign language audiences may have actually have acted to 'complement the more explicitly political content of news and enable the BBC to reach further and deeper than it might otherwise do,' as it did across Iranian radio-listening cultures. ${ }^{86}$ Regardless of the degree of informational engagement with $\mathrm{BBC}$ news, we can posit that the transnational identities of listeners engaging with musical content, wherever they may have existed, 'allow[ed] for the crafting of relationships with China that worked both within and against state identity-making projects, multicultural politics, and transnational flows. ${ }^{87}$ The research presented in this paper likewise suggests that transnational communication technology of radio broadcasts spurred listeners across national boundaries to work both within and against British and American state-sponsored ideological informational projects by listening to such language-free 'light' music. Their partial rejection of informational broadcasts hyper-tuned towards 'national language,' 'pure' dialectical presentation, and politically-curated terminology in favour of musical entertainment signals but one way in which the transnational realities of radio broadcasts in the region shaped popular culture both within yet also beyond the confines of British and American political and ideological projects.

This paper has only addressed British and American nations' attempts to broadcast Chinese language material towards the 'Far East,' and it remains to be seen whether similar conditions existed for other popular broadcasts towards China, such as the Taiwanese Guomindang Voice of Free China, the French Radio France Internationale or the Soviet Union's Moscow Radio. It is my hope that further 
research on the subject will continue to illuminate how media has historically functioned in transnational contexts throughout the region, and what further lessons we can learn from the study of language and propaganda within such contexts.

\section{Disclosure}

The research that forms this paper was sponsored in part by the United States Bureau of Educational and Cultural Affairs Fulbright-Hays Doctoral Dissertation Research Abroad (DDRA) Fellowship program (2020) and the University of North Carolina-Kings College London Transatlantic Workshop (2019).

\section{Notes on Translation}

This paper uses simplified characters and the pinyin system of Roman character transliteration, except when directly quoting British and American information officials from the period, who often used the 'Wade-Giles’ system of transliteration. For example, the author refers to the term '国语' as 'guoyu' ('national language') except when directly quoting British or American officials from the period of study, who used the term 'kuoyu.'

\section{List of Abbreviations}

PRC-People's Republic of China

ROC-Republic of China

USIA-United States Information Agency

USIS-United States Information Services

BBC-British Broadcasting Corporation

IRD-Information Research Department

VOA-Voice of America

TNA-The National Archives, Kew, UK

BBC WAC-British Broadcasting Corporation Written Archive Centre, Caversham, UK

NARA-National Archives and Records Administration, Maryland, USA 


\section{Notes}

1. Michelle Hilmes, "The New Vehicle of Nationalism: Radio Goes to War," in Jonathan Auerbach and Russ Castronovo, eds. The Oxford Handbook of Propaganda Studies (Oxford: Oxford University Press, 2013), 202.

2. Michelle Hilmes, Network Nations: A Transnational History of British and American Broadcasting (New York: Taylor \& Francis, 2012), 2.

3. The BBC and VOA rebroadcast Mandarin language script materials in Cantonese, Amoy, and Hokkien dialects for varying amounts of time across this period of study. Mandarin language broadcasts were the clear focus of their broadcasting efforts towards ethnic-Chinese speakers in the region, and broadcast times in other dialects never outpaced Mandarin within either organisation.

4. Stephanie Seul and Nelson Ribiero, “Revisiting Transnational Broadcasting: The BBC’s Foreign-Language Services during the Cold War,” Media History 21, No. 4 (2015): 366.

5. For national language as an incomplete state-sponsored project that disproportionately upholds the dominant idea of a stable and unified nation, see Timothy Mitchell, "The Limits of the State: Beyond Statist Approaches and Their Critics,” The American Political Science Review 85, no. 1 (1991), 84-5. See also Prasenjit Duara, Rescuing History from the Nation: Questioning the Narratives of Modern China (Chicago: University of Chicago Press, 1995).

6. For examples of this language standardisation process in Chinese contexts, see Thomas Mullaney, Coming to Terms with the Nation: Ethnic Classification in Modern China (Berkeley: University of California Press, 2010).

7. David Page, "Language, Nationhood, and Diaspora at the BBC Urdu Service, 1940-2010," in Diasporas and Diplomacy : Cosmopolitan Contact Zones at the BBC World Service: 1932-2012, ed. Marie Gillespie, and Alban Webb (London: Routledge, 2012), 158.

8. "Propaganda and the Uncommitted Nation," 13 November 1958, United States Information Agency Office of Research and Intelligence, Record Group 306, Box 2, Entry \#A1 1029 “Research Notes 1958-1962,” National Archives and Records Administration, College Park, Maryland (NARA).

9. For more on the circulation of music within and across transnational communities of listeners during the Chinese high-socialist period, see Barbara Mittler, Dangerous Tunes: The Politics of Chinese Music in Hong Kong, Taiwan, and the People's Republic of China since 1949 (Weisbaden: Harrassowitz, 1997).

10. For "spatializing power" between nation-states, institutions, and individuals, see Dana Mustata, "Geographies of Power: The Case of Foreign Broadcasting in Dictatorial Romania," in Airy Curtains in the 
European Ether: Broadcasting and the Cold War, ed. Alexander Badenoch, Andreas Fickers, and Christian Henrich-Franke (Baden-Baden, Germany: Nomos, 2013), 151.

11. D.M. Hodson, "Reuters Report of the Fall-Out Warning from Peking," 13 November 1961, E1/1801/1, BBC WAC.

12. Alban Webb, London Calling: Britain, the BBC Service, and the Cold War (London: Bloomsbury, 2014), 2-3. See also Seul and Ribiero, “Revisiting Transnational Broadcasting,” 366.

13. Phillip Deery, “The Terminology of Terrorism: Malaya, 1948-52,” Journal of Southeast Asian Studies, 34, no. 2 (June 2003): 235-6.

14. Kuoyu Broadcast Transcripts, 1 January 1968-15 January 1968, box no. 1, microfilm, BBC WAC.

15. “Peking NCNA International Services,” 19 February 1972, FBIS Daily Report 22c, no. 36, February 1972, A9.

16. This information comes largely from two oral history projects, The Association for Diplomatic Studies and Training Foreign Affairs Oral History Project Information Series, and the Midwest China Center’s Oral History Project. The author was not involved with either project, and only consulted transcriptions of individuals working on information policy in the "Far East" region from 1949-1976.

17. Guobin Yang, “A Portrait of Martyr Jiang Qing': The Chinese Cultural Revolution on the Internet,” in Re-envisioning the Chinese Revolution: The Politics and Poetics of Collective Memories in Reform China, ed. Ching Kwan Lee and Guobin Yang (Stanford: Stanford University Press, 2007), 300-1.

18. Tony Crowley, Standard English and the Politics of Language (Champaign, University of Illinois Press, 1989). Donald Raleigh, “Languages of Power: How the Saratov Bolsheviks Imagined Their Enemies," Slavic Review 57, 2 (1998): 320-349.

19. James Milroy and Leslie Milroy, Authority in Language: Investigating Standard English (New York, Taylor \& Francis, 2012); David Moser, A Billion Voices: China’s Search for a Common Language (Sydney: Random House Australia, 2016); Glen Peterson, The Power of Words: Literacy and Revolution in South China (Vancouver: UBC Press, 2000); Gina Anne Tam, Dialect and Nationalism in China, 1860-1960 (United Kingdom: Cambridge University Press, 2020), 147.

20. Gertrude M. Miller, BBC Pronouncing Dictionary of English Names (Oxford, Oxford University Press, 1971.

21. David Goodman, Radio's Civic Ambition: American Broadcasting and Democracy in the 1930s (Oxford: Oxford University Press, 2011), 27.

22. Ibid.

23. Bob Hodge and Kam Louie, The Politics of Chinese Language and Culture: The Art of Reading Dragons (London: Routledge, 1998), 31. 
24. Siew Min Sai, "Mandarin Lessons: Modernity, Colonialism, and Chinese Cultural Nationalism in the Dutch East Indies, c. 1900," Inter-Asia Cultural Studies 17, 3 (2016): 375-394.

25. George P. Jan, “Radio Propaganda in Chinese Villages," Asian Survey 7, no. 12 (1967): 305-315.

26. “Listening to the Voice of America in Communist China," 31 September, 1958, RG 306, Box 1, NARA. See also H.R. Howse, “Listening in Mainland China: Appended Note to Mrs. K Digby Worsley,” 28 June 1965, $\mathrm{E} 3 / 1,39 * 0 / 1, \mathrm{BBC}$ WAC.

27. H.R. Howse, “Chinese Expansion: Draft Publicity for Release to British Press,” 28 October 1965, E1/1, 797/1, BBC WAC.

28. P.G.F. Dalton, “Broadcasting in Chinese," 1 June 1964, FO 1110/1853, TNA. For increase in broadcasting, see Howse, “Chinese Expansion: Draft Publicity for Release to British Press,” E1/1, 797/1, BBC WAC.

29. J.B. Millar, “Correspondence to Mr. Evans,” 21 September 1950, CO 537/7541, TNA.

30. Michael Nelson, War of the Black Heavens: The Battles of Western Broadcasting (Syracuse: Syracuse University Pess, 1997), 26-7.

31. David Clayton, “The Consumption of Radio broadcast Technologies in Hong Kong, 1930-1960,” The Economic History Review 57, no. 4 (2004): 711-2.

32. Vestel Lott, “World Audience for the Voice of America," 4 September 1952, RG 59, Entry 315, Box 5A, NARA. Some Voice of America programming was also transmitted by medium wave transmitters located near American military bases in Okinawa and Northern Luzon, and Guomindang Nationalist Chinese radio stations in Taiwan (Formosa) often conducted relays of VOA material, see P.J. Saynor, "Survey of Listening in Hong Kong, 1955," 22 November 1955, E3/1, 391/1, BBC WAC.

33. Lott, "World Audience for Voice of America," RG 59, NARA.

34. Ibid.

35. "Examples of VOA Effectiveness," Reports and Studies 1949-1953, RG 306, Box 1, NARA. For evidence of listening in Ningxia see Jiemi Shike: Touting 'Ditai' Meiguo zhiyin [Decrypting the Moment: Listening to The Voice of America ‘Enemy Radio’], video interview with Ruan Ming, 11:00, https:/www.youtube.com/ watch?v=HNBr_toEqdM, accessed 18 May 2020.

36. Webb, London Calling, 86.

37. Nelson, War of the Black Heavens, 27.

38. Satu Salmi, "BBC World Service Marketing and Communications: Opinion Formers in China Summary Report," February 1998, E3/1/390/3, BBC WAC.

39. P.G.F. Dalton, “Broadcasting in Chinese," 1 June 1964, FO 1110/1853, TNA. 
40. Nien-Sheng Lin, International Broadcasting to the 'Overseas Chinese,': Audience Analysis and Programming Strategies (Ph.D. Diss.: University of Wisconsin, 1976).

41. K.M. Draycott, "Present Position Regarding Broadcasting in Chinese," 7 February 1964, FO 1110/1853, TNA.

42. See Wanning Sun and John Sinclair, eds., Media and Communication in the Chinese Diaspora London: Routledge, 2015). See also Wanning Sun, Media and the Chinese Diaspora: Community, Communications, and Commerce (London, Routledge, 2006).

43. Peter Hume, "Correspondence to Eric Robertson,” 4 April 1951, E1/614/4 BBC WAC.

44. P.G.E. Nash, “Correspondence with Humphrey Trevelyan, 23 March 1955, E1/1, 797/1, BBC WAC.

45. Nelson, War of the Black Heavens, 26-7.

46. Donald MacFarlane, “Correspondence to Eric Robertson,” 21 April 1951, E1/614/4 BBC WAC.

47. “Report by Foreign Office Committee of Enquiry: Overseas Information Services," 14 July 1952, CAB $129 / 54 / 9$, TNA.

48. Ibid.

49. H.R. Howse, “Chinese Refugee Views on Selected Tapes from BBC Chinese Service,” 13 August 1965, E3/1, 390/1, BBC WAC.

50. Ibid.

51. Ibid.

52. “Voice of America Daily Broadcast Content Reports and Script Translations, 1950-1955,” March 1950, RG 306, Box 2, NARA. See also G. Lewis Schmidt, “Interview with Walter Nichols,” 10 October 1989, transcript of an oral history interview, The Association for Diplomatic Studies and Training Foreign Affairs Oral History Project Information Series: online, https://tile.loc.gov/storage-services/service/mss/ mfdip/2004/2004nic02/2004nic02.pdf

53. David F. Krugler, The Voice of America and Domestic Propaganda Battles, 1945-1953 (Columbia: University of Missouri Press, 2000), 94-101.

54. Shmidt, "Interview with Walter Nichols," 10 October 1989, The Association for Diplomatic Studies and Training Foreign Affairs Oral History Project Information Series.

55. Peter Hume, "Correspondence to Eric Robertson,” 4 April 1951, E1/614/4 BBC WAC.

56. Walter Graham, “Extracts of Interviews with Mr V. Farmer and Mr C. Tarr,” 3 October 1951, E1/614/4 BBC WAC.

57. Ibid.

58. Ibid. 
59. Andrew Stark, “Correspondence to Mr. McCall,” 21 April 1951, E1/614/4 BBC WAC.

60. Donald MacFarlane, “Correspondence to Eric Robertson,” 21 April 1951, E1/614/4, BBC WAC. See the same issue raised three years later by Humphrey Trevelyan, “Correspondence with P.G.E. Nash, 24 March 1955, E1/1, 797/1, BBC WAC.

61. P.G.E. Nash, “BBC Overseas Listener Research Report: Chinese Listener Competition,” December 1950, E1/614/4, BBC WAC

62. I.D. Kingsley, "BBC External Broadcasting Audience Research: Far Eastern Service Report on Chinese Listener Competition March 1954,” 25 October 1954, E1/1, 797/1, BBC WAC.

63. P.G.E. Nash, “Correspondence with Humphrey Trevelyan, 23 March 1955, E1/1, 797/1, BBC WAC.

64. H.R. Howse, "Summary of Views of a Panel of Chinese Refugees in Hong Kong of BBC Chinese Services Output,” 13 August 1965, E3/1, 391/1, BBC WAC.

65. Leo Lowenthal, “September VOA highlights,” 6 October 1950, RG 59, Entry \#315, Box 1, NARA.

66. "Listening to the Voice of America in Communist China," RG 306, NARA.

67. Ibid.

68. Saynor, "Survey of Listening in Hong Kong, 1955," E3/1, 391/1, BBC WAC.

69. Ibid.

70. H.R. Howse, “Listening in Mainland China: Appended Note to Mrs. K Digby Worsley,” 28 June 1965, E3/1, 390/1, BBC WAC.

71. Ibid.

72. Jiemi Shike: Touting 'Ditai’ Meiguo zhiyin, accessed 8 November 2019.

73. Zhong Acheng, “Ting ditai” [Listening to Enemy Radio], in Bei Dao and Li Tuo, eds., Qishi niandai [The 1970s] (Hong Kong: Oxford University Press, 2008), 139.

74. Ibid., 140.

75. Ibid., 137.

76. Ibid., 139.

77. Chunyizhi bingxue rong (a penname meaning 'The Stirrings of Spring Melt the Snow'), "Shouting ditai de gushi” [A Story about Listening to Enemy Radio], 6 September 2010, Maoyan kanren, http://m.kdnet.net/ share-6431109.html, accessed March 9, 2020.

78. “Touting ditai: Bise shiqi de jingshen leyuan” [Listening in to Enemy Radio: A Spiritual Playground During Blocked-off Times] 15 July 2015, Zhongguo xinwen zhoukan yinaihe wo yao pinglun, https://news. qq.com/a/20100728/001771_1.htm 
79. Liu Jinming, “Guanyu 'toutingditai,' ni tingguo shenme haowan de gushi?” [In Regards to 'Listening in to Enemy Radio,' What Fun Stories do you Have?” Zhihu, 11 January 2015, https://www.zhihu.com/ question/28797135, accessed 20 August 2019.

80. “Radio Jamming-Hong Kong," 16 September 1963, CO 1030/1714, TNA. For information on “The Firedrake" folk song as a signature of Chinese radio jamming, at least since 2001 but probably earlier, see Jerome S. Berg, Broadcasting on the Short Waves: 1945 to Today (Jefferson, NC: MacFarland, 2008), 47.

81. David E. Reuther, “Neal Donnelly interviewed by David E. Reuther," 11 December 2001, The Association for Diplomatic Studies and Training Foreign Affairs Oral History Project Information Series. See also L.P. Breen, “Listening in China,” 28 September 1976, E3/1, 390/1, BBC WAC. See also, Derek Brooke-Wavell, “Report on Duty Tour to China from $1^{\text {st }}$ December to $16^{\text {th }}$ December 1975 ,” January 1976, FCO 95/1888, TNA.

82. Tam, Dialect and Nationalism, 191.

83. Ibid., 1.

84. Mitchell, "The Limits of the State," 84-5.

85. Barbara Mittler, A Continuous Revolution: Making Sense of Cultural Revolution Culture (Cambridge: Harvard University East Asia Center, 2012). See also Mittler, Dangerous Tunes.

86. Jason Toynbee and Leili Sreberny Mohammadi, “Diaspora Calling the Homeland? The BBC Persian Service, Cosmopolitanism and Music Listening in Iran," in Marie Gillespie, and Alban Webb, eds., Diasporas and Diplomacy : Cosmopolitan Contact Zones at the BBC World Service: 1932-2012 (London: Routledge, 2012), 174.

87. Andrea Louie, Chineseness Across Borders: Renegotiating Chinese Identities in China and the United States (Durham: Duke University Press, 2004), 202.

\section{Biography}

Donald Santacaterina is a Ph.D. Candidate at UNC Chapel Hill whose work revolves around global media systems, newspaper culture, and domestic propaganda in the People's Republic of China since 1949. 


\section{TMG Journal for Media History}

Volume 24 No $(1 / 2) / 2021$

\section{DOI}

https://dx.doi.org/10.18146/tmg.778

\section{PUBLISHER}

Netherlands Institute for Sound and Vision

\section{COPYRIGHT}

Each article is copyrighted (c) by its author(s) and is published under license from the author(s). When a paper is accepted for publication, authors will be requested to agree with the Creative Commons Attribution 4.0 International License. 